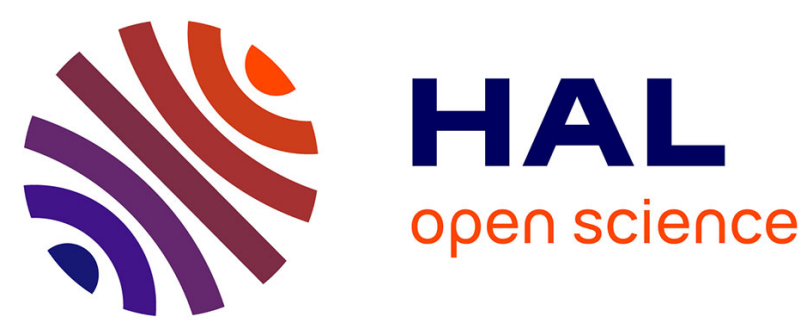

\title{
Lithium and Brine Geochemistry in the Salars of the Southern Puna, Andean Plateau of Argentina
}

Romina Lucrecia Lopez Steinmetz, Stefano Salvi, Carisa Sarchi, Carla

Santamans, Lorena Cecilia Lopez Steinmetz

\section{- To cite this version:}

Romina Lucrecia Lopez Steinmetz, Stefano Salvi, Carisa Sarchi, Carla Santamans, Lorena Cecilia Lopez Steinmetz. Lithium and Brine Geochemistry in the Salars of the Southern Puna, Andean Plateau of Argentina. Economic Geology, 2020, 115, pp.1079 - 1096. 10.5382/econgeo.4754 . hal02989895

\section{HAL Id: hal-02989895 \\ https://hal.science/hal-02989895}

Submitted on 5 Nov 2020

HAL is a multi-disciplinary open access archive for the deposit and dissemination of scientific research documents, whether they are published or not. The documents may come from teaching and research institutions in France or abroad, or from public or private research centers.
L'archive ouverte pluridisciplinaire HAL, est destinée au dépôt et à la diffusion de documents scientifiques de niveau recherche, publiés ou non, émanant des établissements d'enseignement et de recherche français ou étrangers, des laboratoires publics ou privés. 


\author{
Romina Lucrecia López Steinmetz ${ }^{1}{ }^{*}$, Stefano Salvi ${ }^{2}$, Carisa Sarchi ${ }^{1}$, Carla Santamans ${ }^{1}$, \\ Lorena Cecilia López Steinmetz ${ }^{3}$
}

${ }^{1}$ CONICET (INECOA), Instituto de Geología y Minería, Universidad Nacional de Jujuy, Av. Bolivia 1661, S.S. de Jujuy 4600, Argentina

${ }^{2}$ Université de Toulouse, CNRS, GET, IRD, OMP, 14 Av. Edouard Belin, Toulouse 31400, France

${ }^{3}$ Instituto de Investigaciones Psicológicas (IIPsi-UNC-CONICET), Universidad Nacional de Córdoba, Boulevard de la Reforma y Enfermera Gordillo s/n., 2do piso, Córdoba 5000, Argentina

*corresponding author: lucrecialopezsteinmetz@hotmail.com

\title{
Abstract
}

The Andean plateau is a small region of South America extending between northwest Argentina, southwest Bolivia and northern Chile. It concentrates the largest global resources of lithium brines in its numerous salars. Of these, the giant salars in Bolivia and Chile have been relatively well studied, however, only little is known about the smaller, but numerous salars in the Argentine Puna region. In this article, we present the results of the first regional-scale reconnaissance exploration of the twelve major salars situated in the southern part of the Puna plateau $\left(24^{\circ} \mathrm{S}-26^{\circ} 30^{\prime} \mathrm{S}\right)$. Hydrochemical data indicate that shallowest brines are characterized by highly variable Li concentrations, with mean Li grades ranging between 57 and $570 \mathrm{mg} \mathrm{L}^{-1}$, and mean Li:Mg ratios from 0.01 to 1.24 . A survey of the brine chemistry of the salars across 
the Puna plateau, including its northern part, has revealed the absence of geographical pattern in $\mathrm{Li}^{+}$grade distribution. However, a comparison among mean $\mathrm{Li}^{+}$grades, $\mathrm{Li}^{+}: \mathrm{Mg}^{2+}$ ratios, and the size of all salars allows an estimation of their Li mining potential. Specifically, the salt pan of Arizaro represents the high potential mainly due to its size; Antofalla-Botijuelas has a large surface and promising $\mathrm{Li}: \mathrm{Mg}$ ratios for Li recovering via brine evaporation, though its elongated shape is a constraint; Pastos Grandes, Pozuelos, and Rincón have encouraging Li grades, interesting salar sizes, and relatively easy access. Olaroz, Cauchari, and Hombre Muerto contain the highest $\mathrm{Li}^{+}$grades in brines of all of the Argentine Puna, and embody the most interesting perspectives of the Argentine plateau and in a regional context. Salar sizes could be related to maximum $\mathrm{Li}^{+}$grade of brines. Larger salars would be then expected to contain higher $\mathrm{Li}^{+}$grade brines than smaller ones, which could be considered as a useful criterion for surveys of brinetype deposits.

Keywords: lithium triangle; salt pan; Central Andes; hydrochemistry 
Within the past few years, it has become apparent that the global need for an energy

transition from fossil fuels depends not only on our capacity to come up with a renewable source of energy, but also on our ability to store it. The success of Li-ion batteries, with early applications in mobile electronics and now increasingly in electric and hybrid vehicles, has caused batteries to become the prime source of Li consumption, worldwide. This has spurred a renewed interest on lithium as a resource, to the point that it is now considered one of the most critical materials of our times (e.g., Hache et al., 2018; Olivetti et al., 2017; Ghadbeigi et al., 2015). One of the principal sources of lithium is the mineral spodumene (along with petalite and lepidolite), found mainly in highly evolved pegmatites, with Australia being its largest producer (mainly from Greenbush; Kesler et al., 2012). Processing, however, is carried out mostly in China, which is also the world's largest consumer of this metal (Sun et al., 2017). Another abundant source of lithium is the dissolved salt in modern brine deposits found in evaporated altitude lakes, known as salars. The Andean plateau, located between Bolivia, Chile and Argentina (also known as the lithium triangle), hosts numerous salars, and the region contains more than $50 \%$ of the global Li resources (Munk et al., 2016). This form of lithium is more easily processed than hard rock, causing Chile to become the largest exporter of the finished product, lithium carbonate (Sun et al., 2017; Hache et al., 2018). This resource represents therefore a strategic supply of lithium for the western world.

The largest known Andean salar is the giant Uyuni salar $\left(10,580 \mathrm{~km}^{2}\right)$ in Bolivia (Ericksen and Salas, 1977; Risacher and Fritz, 1991), although this country is not a producer. Second in size is the Salar de Atacama in Chile, which, with its $3,000 \mathrm{~km}^{2}$ at mean grades of $1,400 \mathrm{mg} \mathrm{L}^{-1}$, is the most important lithium resource in the world (Ide and Kunasz, 1989; Kunasz, 2006). Argentina also has an enormous potential for lithium brine resources, with sixteen of the remaining major salars located in this country's portion of the Andean plateau, 
known as the Puna region (Fig. 1). The Puna plateau is divided into northern and southern parts. The Northern Puna (located between $c a \cdot 22-24^{\circ} \mathrm{S}$ ) hosts the salars of Guayatayoc, Salinas Grandes, Olaroz, Cauchari, and Jama, which range in size between 25 and $280 \mathrm{~km}^{2}$ and contains brines ranging between about 80 and $1,000 \mathrm{mg} \mathrm{L}^{-1}$ in mean $\mathrm{Li}^{+}$concentrations (López Steinmetz, 2017; López Steinmetz et. al., 2018; García et al., 2019). Among these salars, Olaroz and Cauchari have the highest $\mathrm{Li}^{+}$grades (means of $1,014 \mathrm{mg} \mathrm{L}^{-1}$ and $860 \mathrm{mg} \mathrm{L}^{-1}$, respectively), and are presently being mined. Although the twelve salars in the Southern Puna plateau (south of $24^{\circ}$ S; Fig. 1) constitute a huge resource, only the Salar de Hombre Muerto is being currently operated. All of these salars have been staked for mining rights, however very little is known of the brine hydrochemistry of the Southern Puna's salars, except that mean $\mathrm{Li}^{+}$grades of 520 and $400 \mathrm{mg} \mathrm{L}^{-1}$ have been reported for Hombre Muerto (Garret, 2004; Kesler et al., 2012; Godfrey et al., 2013) and Rincón (Ovejero Toledo et al., 2009), respectively, and an isotopic data set is available for the Salar de Centenario and Ratones (Orberger et al., 2015).

This manuscript reports the outcome of a large effort to obtain data from the 12 major salars scattered throughout the very remote Southern Puna region. It is the result of a two-year regional exploration campaign carried out by the CONICET and the Institute of Geology and Mining of the Jujuy University of Argentina. Along with the information previously reported by López Steinmetz (2017) and López Steinmetz et al. (2018) on the northern Puna salars, its aim is to contribute to knowledge of the hydrochemistry of the Andean salars, and to complete the first broad survey of Li-bearing salars hosted on the Argentine plateau. This study concludes the Li survey and brines chemistry characterization of Andean salars, offering for the first time an overview of the true potential of the Andean Lithium Triangle. 

major volcanic peaks that mark the Chilean-Argentinian border, such as the Llullaillaco $(6,723$ m a.s.1.), Socompa (6,031 m a.s.1.), and Rincón (5,594 m a.s.1.), and by the Luracatao Range to the east (Figs. 2 and 3; cf. Alonso et al., 1984). The salars in this study are located in orographic depressions along NE-SW trending ranges that formed during uplift of the Andes. The main geology consists of Paleozoic basement units; these include: i) Ordovician metasediments (Copalayo, Caucota, and Falda Ciénaga formations; Turner, 1960; Aceñolaza, 1973), submarine volcanic rocks (Schwab, 1973; Coira, 1979), riodacites, granites (Eastern Puna Eruptive Belt, Taca-Taca, Macón, Arita, and La Casualidad; Méndez et al., 1973; Turner and Méndez, 1979; Méndez et al., 1979); ii) Devonian marine sandstones (Salar del Rincón Formation); iii) Carboniferous continental sandstones (Cerro Oscuro Formation); and iv) Permian marine limestones (Arizaro Formation; Aceñolaza et al., 1972; Donato and Vergani, 1985; Galli et al., 2010).

Middle Eocene to upper Pliocene continental sedimentary rocks (Pastos Grandes Group; Turner, 1960; Alonso, 1986; Alonso et al., 1991) are exposed along the Calalaste and Los Colorados Ranges (Fig. 2A). Large areas of the Southern Puna are covered by upper Oligocene - Pliocene dacites, andesites, ignimbrites, and Quaternary basalts (Salfity et al., 1984; Alonso and Viramonte, 1987; Jordan and Alonso, 1987; Montero López et al., 2015; Maro et al., 2017). Quaternary fine-grained sediments of alluvial origin cover the planes between the mountain ranges. Salt pans form on low-laying areas because of the extreme climatic conditions that prevail in these high-altitude endorheic basins (cf. López Steinmetz and Galli, 2015).

\section{Methods}

Between 2014 and 2017, 6 expeditions were run to the Southern Puna of Argentina in order to sample residual brines from the twelve major salars in this region. These are the Salar 
113 de Centenario (CE), Diablillos (DI), Hombre Muerto (HM), Incahuasi (IN), Pastos Grandes

114 (PG), Pozuelos (PZ), Ratones (RA), Antofalla-Botijuelas (AN), Arizaro (AR), Pocitos-Quirón

115 (PC), Rincón (RI), and Río Grande (RG, Figs. 2 and 3). Precise sample location is provided in

116 Table A1 of the Appendix. Most samples were collected in pits that were hand-dug in the salars,

117 at depth intervals of 40 to $90 \mathrm{~cm}$, plus a number that were taken directly from brine pools

118 (samples CE1, CE2, DI3 to DI5, PG1 to PG3, PG5, PZ1, PZ5, PZ7, PZ8, AN1, AN2, PC1 to

119 PC4, and RI 5). Samples were stored in pre-cleaned, 2-L polyethylene bottles and kept at $5^{\circ} \mathrm{C}$

120 in the field. No acidification was employed after sample collection. Samples were transported

121 directly to the laboratory after collection.

All samples collected in the twelve salars were analyzed at the Agua de Los Andes S.

A. laboratory (Jujuy, NW Argentina) and the resulting data are shown in Table 1. Values for $\mathrm{pH}$ and electrical conductivity were determined with a Hanna HI2314 multi-range conductivity meter. The calibration of the meter involved several steps. 1) Verification of the temperature reading; 2) calibration of the conductivity meter using a $1,000-\mu \mathrm{S} / \mathrm{cm}$ calibration standard, to obtain a conductivity cell constant of $5.0+/-0.5$; and 3 ) calibration of the $\mathrm{pH}$ meter using buffer solutions for $\mathrm{pH} 7$ and 4, to obtain a slope comprised between 55 and $60 \mathrm{mVs}$. Salinities are expressed as the total dissolved solids (TDS; $\mathrm{mg} \mathrm{L}^{-1}$ ), which were obtained by employing a conversion factor of 0.50 on the measured electrical conductivity. This conversion factor corresponds to the ratio observed between the measured electrical conductivity of samples and their total analytical ionic concentrations (i.e., the sum of measured cations and anions). The major ion composition was determined following the procedure outlined by Clesceri et al. (1998). Concentrations of calcium $\left(\mathrm{Ca}^{2+}\right)$ were obtained by titrating with a $0.01 \mathrm{M}$ EDTA solution for the former, while those of magnesium $\left(\mathrm{Mg}^{2+}\right)$ were calculated by subtracting the calcium concentration to the total hardness. Titration with a $0.01-\mathrm{N}$ sulfuric acid solution was employed to determine carbonate and bicarbonate ion $\left(\mathrm{HCO}_{3}{ }^{-}\right.$and $\left.\mathrm{CO}_{3}{ }^{2-}\right)$ concentrations, using 
methyl-orange and phenolphthalein, respectively, as end-point indicators. Chloride $\left(\mathrm{Cl}^{-}\right)$was measured by titration using the argentometric method. Concentrations of sulfate $\left(\mathrm{SO}_{4}{ }^{2-}\right)$ were determined by turbidimetry on the precipitate obtained by mixing it with $\mathrm{BaCl}_{2}$ in an acetic acid medium. Atomic Emission Spectroscopy was employed to analyse sodium $\left(\mathrm{Na}^{+}\right)$, potassium $\left(\mathrm{K}^{+}\right)$and lithium $\left(\mathrm{Li}^{+}\right)$while boron $(\mathrm{B})$ was determined by colorimetry using a carmine reactive. Ion balance values were $\leq 10 \%$ in all cases (cf. Fig. A1 and Table A2, Appendix).

\section{Li-Bearing Salars of the Southern Puna}

\subsection{Salar de Centenario (CE, east)}

Centenario is a $7-\mathrm{km}^{2}$ playa lake located at 3,816 m a.s.1., between the Los Colorados, Pastos Grandes, and Luracatao Ranges (Fig. 2). Centenario also includes $70 \mathrm{~km}^{2}$ of saline muddy shore zones, which are fed by the Singuel, Ciénaga Grande, and Copalayo rivers.

Brines collected in the Salar de Centenario are alkaline, with $\mathrm{pH}$ values comprised between 7.50 and 7.70, and TDS ranging between 26,090 and 48,590 $\mathrm{mg} \mathrm{L}^{-1}$ (Table 1). According to their major chemical composition, brines are of the $\mathrm{Na}^{+} / \mathrm{Cl}^{-}-\mathrm{SO}_{4}^{2-}$ type, with high $\mathrm{SO}_{4}{ }^{2-}$, relatively abundant $\mathrm{K}^{+}$and $\mathrm{Mg}^{2+}$, and are depleted in $\mathrm{Ca}^{2+}$ (Fig. 4). No correlation between major ions has been identified, with the exception of sample CE4, whose $\mathrm{Na}^{+}: \mathrm{Cl}^{-}$ratio $\sim 1: 1$ reflects equilibrium solubility of halite (Fig. 5).

The $\mathrm{Li}^{+}$concentration in the Salar de Centenario ranges between 25 and $377 \mathrm{mg} \mathrm{L}^{-1}$, with a mean $\mathrm{Li}^{+}$concentration of $141 \mathrm{mg} \mathrm{L}{ }^{-1}$. Positive correlations could exist between the $\mathrm{Li}^{+}$ concentrations and those of $\mathrm{K}^{+}, \mathrm{B}$, and $\mathrm{Mg}^{2+}$ (Fig. 6). The mean $\mathrm{Li}: \mathrm{K}$ ratio is 0.37 while the mean Li:Mg ratio is 0.20 (Table 2). Boron concentrations range between 277 and $581 \mathrm{mg} \mathrm{L}^{-1}$, and the mean Li:B ratio is 0.97 . 
Diablillos is a $4-\mathrm{km}^{2}$ playa lake located at $4,032 \mathrm{~m}$ a.s.1., between the Los Colorados, Luracatao and Pastos Grandes Ranges (Fig. 2). Muddy shore zones covering about $29 \mathrm{~km}^{2}$ at the mouth of the Diablillos river, to the east, are also considered as part of the Salar de Diablillos.

The Diablillos brines are alkaline, $\mathrm{pH}$ is 8.00 , and TDS values range between 26,350 and $80,735 \mathrm{mg} \mathrm{L}^{-1}$ (Table 1). According to their major chemical composition, brines are of the $\mathrm{Na}^{+} / \mathrm{Cl}^{-}-\mathrm{SO}_{4}{ }^{2-}$ type, with high $\mathrm{SO}_{4}{ }^{2-}$, with relatively abundant $\mathrm{K}^{+}$and $\mathrm{Mg}^{2+}$ (Fig. 4). The $\sim 1: 1$ ratio between $\mathrm{Na}^{+}$and $\mathrm{Cl}^{-}$in samples DI3 and DI4 indicates the dissolution of halite. Brines are also characterized by $\mathrm{SO}_{4}{ }^{2-}>\mathrm{Ca}^{2+}>\mathrm{CO}_{3}^{2-}+\mathrm{HCO}_{3}{ }^{-}$(Fig. 5).

The $\mathrm{Li}^{+}$concentration in the Diablillos's brines ranges between 47 and $357 \mathrm{mg} \mathrm{L}^{-1}$, with a mean $\mathrm{Li}^{+}$concentration of $180 \mathrm{mg} \mathrm{L}-1$. The mean $\mathrm{Li}: \mathrm{K}$ ratio is 0.26 and the mean $\mathrm{Li}: \mathrm{Mg}=$ 0.26 (Table 2). Boron concentrations are up to $808 \mathrm{mg} \mathrm{L}^{-1}$, with a mean Li:B ratio of 0.86 .

\subsection{Salar de Hombre Muerto (HM, east)}

The Salar de Hombre Muerto is located at 3,970 m a.s.l., between the Aguas Calientes, Calalaste, Los Colorados, and Pastos Grandes Ranges, at the foot of the Ratones volcano $(5,252$ m a.s.1.) (Vinante and Alonso, 2006). Hombre Muerto is by far the largest salar among those of the eastern part of Southern Puna. It spreads between 66 53'24'” - 67'13'30'W and $25^{\circ} 13^{\prime} 48^{\prime \prime}$ - 25'30’36”'S (Fig. 2), and includes a $230 \mathrm{~km}^{2}$ salt pan in the west, a $65 \mathrm{~km}^{2}$ lagoon in the eastern side, and a $245 \mathrm{~km}^{2}$ playa domain that mainly develops in its northern reaches, for a total area of $540 \mathrm{~km}^{2}$. The main tributaries are the Ratones river to the north, and the Los Patos river, sourced at the foot of the Galán volcano (5,919 m a.s.1.), which reaches this salar from the southeast. 

between 7.80 and 8.20, and TDS ranging between 31,215 and 205,022 $\mathrm{mg} \mathrm{L}^{-1}$ (Table 1).

According to their major chemical composition, they are of the $\mathrm{Na}^{+} / \mathrm{Cl}^{-}$type, with relatively abundant $\mathrm{K}^{+}$(Fig. 4). The concentrations $\mathrm{Ca}^{2+}$ and $\mathrm{SO}_{4}{ }^{2-}$ in sample $\mathrm{HM} 4$ correspond to a stoichiometric ratio of 1:1, a value that suggest dissolution of gypsum (Fig. 5).

Hombre Muerto contains the highest values of lithium in Southern Puna, with a mean $\mathrm{Li}^{+}$concentration of $570 \mathrm{mg} \mathrm{L}^{-1}$ for a range between 85 and $1,013 \mathrm{mg} \mathrm{L}^{-1}$. The highest grades are found in the middle part of the salar. The mean $\mathrm{Li}: \mathrm{K}$ ratio is 0.69 , and the mean $\mathrm{Li}: \mathrm{Mg}$ ratio is 0.92 (Table 2). Boron concentrations range between 377 and 1,490 $\mathrm{mg} \mathrm{L}^{-1}$, and the mean Li:B ratio is 1.90 (Fig. 6).

\subsection{Salar de Incahuasi (IN, east)}

Incahuasi is a playa lake with an elongated shape oriented north-south. It is situated between the Calalaste and Morada mountain ranges, at an altitude of 3,269 m a.s.1. It is the southernmost salar in the Puna region, spreading between $67^{\circ} 39^{\prime} 03^{\prime \prime}-67^{\circ} 40^{\prime} 35^{\prime \prime} \mathrm{W}$ and $26^{\circ} 18^{\prime} 44^{\prime \prime}-26^{\circ} 28^{\prime} 30^{\prime \prime} \mathrm{S}$ (Fig. 2). Its southern edges are covered by more than $33 \mathrm{~km}^{2}$ of dune fields. This salar includes two distinctive zones; north of $26^{\circ} 23^{\prime 2} 29^{\prime \prime} \mathrm{S}$ is a saline, episodically flooded part, covering about $18 \mathrm{~km}^{2}$, while the $20 \mathrm{~km}^{2}$ to the south consist of a saline muddy playa lake. The salar is mostly fed by the Cortaderas river, coming in from the northeast.

Brines from the Salar de The Incahuasi are slightly alkaline, with a $\mathrm{pH}$ ranging between 6.70 and 7.30. TDS values range between 48,220 and 107,340 $\mathrm{mg} \mathrm{L}^{-1}$ (Table 1). According to their major chemical composition, brines are of the $\mathrm{Na}-\mathrm{Mg}^{2+} / \mathrm{Cl}^{-}$type, with high $\mathrm{Mg}^{2+}$, and depleted in $\mathrm{Ca}^{2+}$ (Fig. 4). Major ratios are characterized by $\mathrm{Cl}^{-}>\mathrm{Na}^{+}, \mathrm{Ca}^{2+}>\mathrm{SO}_{4}{ }^{2-}$, and $\mathrm{Ca}^{2+}>$ $\mathrm{CO}_{3}{ }^{2-}+\mathrm{HCO}_{3}^{-}$(Fig. 5). 
At Incahuasi, the $\mathrm{Li}^{+}$content in brines range between 22 and $145 \mathrm{mg} \mathrm{L}^{-1}$, with a mean

212 of $95 \mathrm{mg} \mathrm{L}^{-1}$. The highest concentrations of Li occur in the middle part of its saline, floodable zone in the north. Brines from Incahuasi contain the highest concentrations of magnesium among all of the salars that are located in the eastern part of the Southern Puna (Fig. 6). $\mathrm{K}^{+}$and $\mathrm{Mg}^{2+}$ concentrations do not correlate with $\mathrm{Li}^{+}$concentrations (Fig. 6); the mean $\mathrm{Li}: \mathrm{K}$ ratio is 0.09 while the mean Li:Mg ratio is 0.01 (Table 2). A positive correlation may exist between B and $\mathrm{Li}^{+}$(Fig. 6). Boron concentrations range between 114 and $570 \mathrm{mg} \mathrm{L}^{-1}$, and the mean $\mathrm{Li}: \mathrm{B}$ ratio is equal to 0.62 .

\subsection{Salar de Pastos Grandes (PG, east)}

The Salar de Pastos Grandes is located at 3,780 m a.s.1. between the Los Colorados,

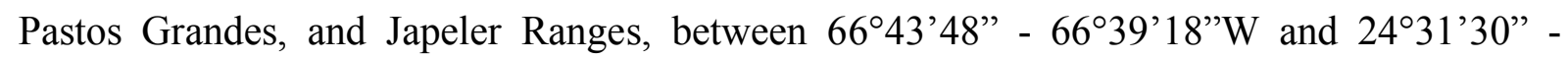
$24^{\circ} 36^{\prime} 18^{\prime}$ 'S (Fig. 2). Pastos Grandes has a triangular shape and the salt pan zones cover $27 \mathrm{~km}^{2}$, to which must be added a $4.80 \mathrm{~km}^{2}$ saline lake, located at its north-eastern margin. The main tributaries are the Corral Colorado and Pastos Grandes rivers in the north, and the Ciénaga Redonda river arriving from the east.

Brines from Pastos Grandes are alkaline, with $\mathrm{pH}$ values ranging between 8.00 and 8.30 , and TDS ranging between 154,030 and $226,600 \mathrm{mg} \mathrm{L}^{-1}$ (Table 1). According to their major chemical composition, brines are of the $\mathrm{Na}^{+} / \mathrm{Cl}^{-}$type, with relatively abundant $\mathrm{Mg}^{2+}$, and depleted in $\mathrm{Ca}^{2+}$ (Fig. 4). When comparing these brines with those from the other salars, the Pastos Grandes shows the highest concentrations of $\mathrm{CO}_{3}{ }^{2-}$ and $\mathrm{HCO}_{3}{ }^{-}$. Near stoichiometric trends between the $\mathrm{Ca}^{2+}: \mathrm{CO}_{3}{ }^{2-}+\mathrm{HCO}_{3}^{-}$and $\mathrm{Ca}^{2+}: \mathrm{SO}_{4}{ }^{2-}$ ratios likely reflect equilibrium solubility of Ca-Mg sulfates and Ca-carbonates (Fig. 5). However, the fact that the linear trend defined by the $\mathrm{Mg}^{2+}: \mathrm{SO}_{4}{ }^{2-}$ data deviates from a 1:1 ratio reflects that $\mathrm{Mg}$ salts, like epsomite 235 $\left(\mathrm{MgSO}_{4} 7 \mathrm{H}_{2} \mathrm{O}\right)$, are not in equilibrium with the brine. 
$\mathrm{L}^{-1}$, with a mean of $483 \mathrm{mg} \mathrm{L}^{-1}$. The highest Li grade zone in the eastern part of the salar. The mean $\mathrm{Li}: \mathrm{K}$ ratio is 0.82 while the mean $\mathrm{Li}: \mathrm{Mg}$ ratio is 0.19 (Table 2). Boron concentrations range between 300 and $812 \mathrm{mg} \mathrm{L}^{-1}$, and the mean Li:B ratio is 2.24 .

4.6. Salar de Pozuelos (PZ, east)

The salar de Pozuelos is a $75-\mathrm{km}^{2}$ salt pan with an oval shape along a NE-SW direction.

It is located at 3,663 $\mathrm{m}$ a.s.l. at the interior of the Los Colorados Range (Fig. 2). The main tributary is the Pozuelos river to the north.

Brines from the Salar de Pozuelos are alkaline, with $\mathrm{pH}$ values ranging between 7.80 and 8.60, and TDS ranging between 205,243 and 298,574 $\mathrm{mg} \mathrm{L}^{-1}$ (Table 1). According to their major chemical composition, brines are of the $\mathrm{Na}^{+} / \mathrm{Cl}^{-}$type, with relatively abundant $\mathrm{K}^{+}$and $\mathrm{Mg}^{2+}$ (Fig. 3). Major ratios are characterized by $\mathrm{Cl}^{-}>\mathrm{Na}^{+}, \mathrm{SO}_{4}{ }^{2-}>\mathrm{Ca}^{2+}$, and $\mathrm{Ca}^{2+}>\mathrm{CO}_{3}{ }^{2-}$

$+\mathrm{HCO}_{3}{ }^{-}$. Non-stoichiometric ratios were observed combining different major ion pairs $\left(\mathrm{Cl}^{-}>\right.$ $\mathrm{Na}^{+}, \mathrm{SO}_{4}{ }^{2-}>\mathrm{Ca}^{2+}$, and $\mathrm{Ca}^{2+}>\mathrm{CO}_{3}{ }^{2-}+\mathrm{HCO}_{3}{ }^{-}$), suggesting that the dominant ion concentrations are independent of salt equilibrium solubility (Fig. 5).

In the Pozuelos's brines, $\mathrm{Li}^{+}$concentrations range between 75 and $940 \mathrm{mg} \mathrm{L}^{-1}$ with a mean of $401 \mathrm{mg} \mathrm{L}^{-1}$. Grades increase towards the central part of the salt pan. Stoichiometric 1:1 ratios are observed between $\mathrm{Li}^{+}$and $\mathrm{K}^{+}$in samples PZ5 and PZ6 (Fig. 6 A). The mean Li:K ratio is 0.69 , and the mean $\mathrm{Li}: \mathrm{Mg}$ ratio is 0.43 (Table 2). Boron ranges between 202 and 2,102 $\mathrm{mg} \mathrm{L} \mathrm{L}^{-1}$, and the mean Li:B ratio is 1.26 .

\subsection{Salar de Ratones (RA, east)}

Ratones is a north-south stretched playa lake located at 3,822 $\mathrm{m}$ a.s.l. between the

Colorados and Pastos Grandes - Luracatao Ranges. The playa lake surface covers only $3 \mathrm{~km}^{2}$, 
with most of the salar consisting of $47 \mathrm{~km}^{2}$ of saline muddy shore zones, spread between $66^{\circ} 47^{\prime} 10^{\prime \prime}-66^{\circ} 50^{\prime} 54^{\prime \prime} \mathrm{W}$ and $25^{\circ} 02^{\prime} 42^{\prime \prime}-25^{\circ} 11^{\prime} 42^{\prime \prime} \mathrm{S}$ (Fig. 2). Main tributaries are the Singuel and Quebrada Honda rivers.

Brines from the Salar de Ratones are alkaline and moderately saline, TDS values are between 28,080 and 82,580 $\mathrm{mg} \mathrm{L}^{-1}$, and $\mathrm{pH}$ range between 7.50 and 7.80 (Table 1). According to their major chemical composition, brines are of the $\mathrm{Na}^{+} / \mathrm{Cl}^{-}-\mathrm{SO}_{4}{ }^{2-}$ type, with relatively abundant $\mathrm{K}^{+}$and $\mathrm{Ca}^{2+}$ (Fig. 4).

The $\mathrm{Li}^{+}$concentration in the Ratones's brines range between 88 and $260 \mathrm{mg} \mathrm{L}^{-1}$, and the mean $\mathrm{Li}^{+}$concentration of the three samples collected in the salt pan zone is $158 \mathrm{mg} \mathrm{L}^{-1}$. The $\mathrm{Li}^{+}, \mathrm{K}^{+}$and $\mathrm{Mg}^{2+}$ mean ratios are: $\mathrm{Li}: \mathrm{K}=0.38$, and $\mathrm{Li}: \mathrm{Mg}=1.24$ (Table 2). Boron concentrations range between 312 and $509 \mathrm{mg} \mathrm{L}^{-1}$, and the $\mathrm{Li}: \mathrm{B}$ ratio $=1.06$.

\subsection{Salar de Antofalla-Botijuelas (AN, west)}

Salars in the western part of the Southern Puna are relatively large. The Salar de Antofalla-Botijuelas covers some $655 \mathrm{~km}^{2}$ with its elongated shape stretching N-S for more than $100 \mathrm{~km}$. This salt pan is at an altitude of 3,330 $\mathrm{m}$ a.s.1., between $25^{\circ} 24^{\prime} 54^{\prime \prime}$ and $26^{\circ} 06^{\prime} 54^{\prime \prime} \mathrm{S}$ at $c a .67^{\circ} 42^{\prime} \mathrm{W}$ (Fig. 3). The salar is delimited by the Calalaste and Antofalla Ranges and main tributaries are the Archibarca, Antofalla, Aguas Calientes, and Aguas Dulces rivers. There are abundant thermal springs around this salar, especially in the northern and central western borders of the salar (Botijuelas thermal sources), and samples AN1, AN2, and AN3 correspond to thermal waters sampled at temperatures of $31.50^{\circ} \mathrm{C}$.

Brines from the Salar de Antofalla-Botijuelas are only slightly alkaline, with $\mathrm{pH}$ values comprised between 7.40 and 7.80, and TDS ranging between 9,110 and 184,570 $\mathrm{mg} \mathrm{L}^{-1}$ (Table 1). According to their major chemical composition, brines are of the $\mathrm{Na}^{+} / \mathrm{Cl}^{-}-\mathrm{SO}_{4}{ }^{2-}$ type, with relatively abundant $\mathrm{Ca}^{2+}$ and low $\mathrm{Mg}^{2+}$ (Fig. 4). 

mg L ${ }^{-1}$, with a mean of $209 \mathrm{mg} \mathrm{L}^{-1}$. Positive trends parallel to $1: 1$ are observed between the $\mathrm{Li}^{+}$

288

\subsection{Salar de Arizaro (AR, west)}

Arizaro, also in western Southern Puna, is the largest salar in the Puna plateau and in Argentina altogether. This salt pan covers an area of $1,708 \mathrm{~km}^{2}$, between $67^{\circ} 18^{\prime} 33^{\prime \prime}$ $68^{\circ} 02^{\prime} 11^{\prime \prime} \mathrm{W}$ and $24^{\circ} 20^{\prime} 42^{\prime \prime}-25^{\circ} 05^{\prime} 44^{\prime \prime} \mathrm{S}$ (Fig. 3). Arizaro is located at an elevation of 3,474 m a.s.l., and is bounded by the Archibarca and Antofalla ranges and by the volcanic peaks that define the Argentinian border with Chile.

Brines from the Salar de Arizaro are alkaline, with $\mathrm{pH}$ values comprised between 7.30 and 7.40, and TDS ranging between 38,865 and 308,175 $\mathrm{mg} \mathrm{L}^{-1}$ (Table 1). According to their major chemical composition, brines are of the $\mathrm{Na}^{+}-\mathrm{K}^{+} / \mathrm{Cl}^{-}-\mathrm{SO}_{4}{ }^{2-}$ type, with relatively abundant $\mathrm{Mg}^{2+}$ (Fig. 4). In addition of being the largest salar of the Argentinean plateau, Arizaro contains the highest concentrations of $\mathrm{K}^{+}, \mathrm{B}$, and $\mathrm{SO}_{4}{ }^{2-}$ of the Southern Puna. No obvious correlation could be observed among data for major ions (Fig. 5). $\mathrm{A} \mathrm{Mg}^{2+}: \mathrm{SO}_{4}{ }^{2-}$ linear trend parallel to the 1:1 ratio indicates some degree of equilibrium solubility for $\mathrm{Mg}$ salts, like epsomite $\left(\mathrm{MgSO}_{4} 7 \mathrm{H}_{2} \mathrm{O}\right)$. However, trends parallel to the $\mathrm{Na}^{+}$and $\mathrm{SO}_{4}{ }^{2-}$ axes suggest the presence of other salts that are not in equilibrium with the brine.

The $\mathrm{Li}^{+}$concentrations in the Salar de Arizaro range between 52 and $465 \mathrm{mg} \mathrm{L}^{-1}$, with an increase towards the south-central part. Mean $\mathrm{Li}^{+}$concentrations for the whole salar are of $191 \mathrm{mg} \mathrm{L}^{-1}$. The mean Li: $\mathrm{K}$ ratio is 0.24 while the mean Li:Mg ratio is 0.16 (Table 2). Boron concentrations range between 380 and $3,382 \mathrm{mg} \mathrm{L}^{-1}$, with a mean Li:B ratio of 0.28 . 
m a.s.l. It is elongated north-south and lays between the Los Colorados and Calalaste Ranges

(Fig. 3). A 10-km long alluvial fan at the mouth of the Los Colorados river separates the Salar de Pocitos to the north from the Quirón playa lake to the south. The Pocitos salt pan zone covers $28 \mathrm{~km}^{2}$ and spreads between $67^{\circ} 00^{\prime} 18^{\prime \prime}-67^{\circ} 03^{\prime} 36^{\prime \prime} \mathrm{W}$ and $24^{\circ} 22^{\prime} 30^{\prime \prime}-24^{\circ} 27^{\prime} 30^{\prime} \mathrm{S}$. The Quirón playa lake has a surface of $422 \mathrm{~km}^{2}$ and spreads between $24^{\circ} 15^{\prime} 18^{\prime \prime}$ and $24^{\circ} 46^{\prime} 12^{\prime \prime} \mathrm{S}$. In addition to the Los Colorados river, another important tributary is the Agua Blanca river that emerges at the foot of the Quevar volcano (6,130 m a.s.1.).

Brines from the Salar de Pocitos-Quirón are alkaline, $\mathrm{pH}$ values range between 7.80 and 8.30, and salinity is high, with TDS ranging between 29,480 and 299,217 $\mathrm{mg} \mathrm{L}^{-1}$ (Table 1). According to their major chemical composition, brines are of the $\mathrm{Na}^{+}-\mathrm{Ca}^{2+}-\mathrm{Mg}^{2+} / \mathrm{Cl}^{-}-\mathrm{SO}_{4}{ }^{2-}$ type (Fig. 3). The Pocitos-Quirón brines contain the lowest concentrations of $\mathrm{Li}^{+}, \mathrm{K}^{+}, \mathrm{Mg}^{2+}$, and B among all salars in the Southern Puna (Fig. 6).

$\mathrm{Li}^{+}$ranges between 22 and $101 \mathrm{mg} \mathrm{L}-1$, with the highest grade zone occurring in the central part of the Pocitos salt pan. The mean $\mathrm{Li}^{+}$concentration is $57 \mathrm{mg} \mathrm{L}^{-1}$, the mean $\mathrm{Li}: \mathrm{K}$ ratio is 0.26 and the mean $\mathrm{Li}: \mathrm{Mg}$ ratio is 0.17 (Table 2). Boron concentrations range between 60 and $208 \mathrm{mg} \mathrm{L}^{-1}$. A strong positive correlation between $\mathrm{Li}^{+}$and $\mathrm{B}$ is observed along the stoichiometric ratio 1:1 (Fig. $6 \mathrm{~B}$ ), and the mean Li:B ratio of these brines is 1.37 .

\subsection{Salar de Rincón (RI, west)}

The Salar de Rincón is a playa lake located at 3,725 m a.s.l., at the foot of the Tultul 


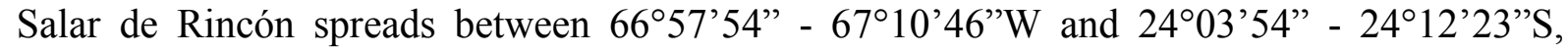
covering a surface of $250 \mathrm{~km}^{2}$. Main tributaries to this salar include the Catua and Huaytiquina rivers, both coming in from the north, causing a $170-\mathrm{km}^{2}$ saline muddy shore zone that spreads up to $23^{\circ} 55^{\prime} 48^{\prime \prime}$ S.

Brines from the Salar de Rincón are alkaline, with $\mathrm{pH}$ ranging between 8.60 and 8.80, and TDS values comprised between 140,265 and 284,650 $\mathrm{mg} \mathrm{L}^{-1}$ (Table 1). According to their major chemical composition, brines are of the $\mathrm{Na}^{+}-\mathrm{K}^{+} / \mathrm{Cl}^{-}-\mathrm{SO}_{4}{ }^{2-}$ type, with relatively abundant $\mathrm{Mg}^{2+}$ (Fig. 4). Major ion concentrations are more elevated in the central part of the salar. Samples along the $\mathrm{Na}^{+}$and $\mathrm{Cl}^{-}$stoichiometric 1:1 ratio suggest equilibrium solubility of halite. Other major ionic ratios are characterized by $\mathrm{SO}_{4}{ }^{2-}>\mathrm{Ca}^{2+}$ and $\mathrm{Mg}^{2+}$, and $\mathrm{Ca}^{2+}>\mathrm{CO}_{3}{ }^{2-}$ $+\mathrm{HCO}_{3}{ }^{-}$(Fig. 5). Linear trends parallel to the $\mathrm{SO}_{4}{ }^{2-}$ axis indicate that the concentrations of $\mathrm{Ca}^{2+}$ and $\mathrm{Mg}^{2+}$ are not controlled by equilibrium solubility of salts (Fig. 5).

Lithium ion concentrations in the Rincón's brines range between 112 and $651 \mathrm{mg} \mathrm{L}^{-1}$, with the highest-grade zone occurring in the central part of the salar, and the mean $\mathrm{Li}^{+}$ concentration being $281 \mathrm{mg} \mathrm{L}^{-1}$. Positive linear trends are observed between $\mathrm{Li}^{+}$and $\mathrm{Mg}^{2+}$ (Fig. 6); the mean $\mathrm{Li}: \mathrm{K}$ ratio is 0.25 while the mean $\mathrm{Li}: \mathrm{Mg}$ ratio is 0.24 (Table 2). Boron concentrations range between 1,405 and $2,098 \mathrm{mg} \mathrm{L}^{-1}$ and the mean $\mathrm{Li}: \mathrm{B}$ ratio is 0.45 .

\subsection{Salar de Río Grande (RG, west)}

The Salar de Río Grande is a 176- $\mathrm{km}^{2}$ elliptically-shaped saline system, oriented northsouth, occurring at an altitude of $3,668 \mathrm{~m}$ a.s.1. between $68^{\circ} 07^{\prime} 22^{\prime \prime}-68^{\circ} 12^{\prime} 07^{\prime \prime} \mathrm{W}$ and $24^{\circ} 59^{\prime} 24^{\prime \prime}-25^{\circ} 06^{\prime} 18^{\prime \prime}$ (Fig. 3). The surface of the salt pan zone covers $56 \mathrm{~km}^{2}$, with remaining of the salar consisting of a $120 \mathrm{~km}^{2}$ saline muddy playa lake that extends to the south of the salar, to $25^{\circ} 10^{\prime} 55^{\prime} \mathrm{S}$. The main tributary is the Río Grande river, which contains some hydrothermal springs in its southernmost headwaters. 

between 199,070 and $284,605 \mathrm{mg} \mathrm{L}^{-1}$. These brines are neutral to slightly alkaline, with $\mathrm{pH}$ ranging between 7.00 and 7.20 (Table 1). According to their major chemical composition, brines are of the $\mathrm{Na}^{+} / \mathrm{Cl}^{-}-\mathrm{SO}_{4}^{2-}$ type, with similar proportions of $\mathrm{K}^{+}, \mathrm{Mg}^{2+}$ and $\mathrm{Ca}^{2+}$ (Fig. 4). Río Grande contains the highest concentrations of $\mathrm{Ca}^{2+}$ and $\mathrm{SO}_{4}{ }^{2-}$ of the Southern Puna (Fig. 5 B). Linear trends parallel to the $\mathrm{SO}_{4}{ }^{2-}$ axis indicate that the concentrations of $\mathrm{Ca}^{2+}$ and $\mathrm{Mg}^{2+}$ are not controlled by equilibrium solubility of salts (Fig. 5).

The concentrations of $\mathrm{Li}^{+}$range between 139 and $692 \mathrm{mg} \mathrm{L}^{-1}$, with the highest $\mathrm{Li}$ grade measured in the central part of the salar. The mean $\mathrm{Li}^{+}$concentration is $396 \mathrm{mg} \mathrm{L}^{-1}$. Positive linear trends, parallel to the $\mathrm{Li}^{+}$axis, suggest that there is no obvious correlation among $\mathrm{Li}^{+} \mathrm{K}^{+}$, and B. However, a stoichiometric linear trend is observed between $\mathrm{Li}^{+}$and $\mathrm{Mg}^{2+}$ (Fig. 6). The mean $\mathrm{Li}: \mathrm{K}$ ratio is 0.72 while the mean $\mathrm{Li}: \mathrm{Mg}$ ratio is 0.33 (Table 2). Boron concentrations range between 303 and $545 \mathrm{mg} \mathrm{L}^{-1}$, the mean $\mathrm{Li}: \mathrm{B}$ ratio $=2.81$.

\section{Discussion}

\subsection{Classification of brines in the regional context}

There are a number of common features that can be distilled from the major chemistry of the brines investigated in this study (Fig. 4). The first observation is that they are all rich in $\mathrm{Na}^{+}$and $\mathrm{Cl}^{-}$and that, at least for most brines, concentrations of $\mathrm{K}^{+}$(e.g., HM, RA, AR, RI) and $\mathrm{Mg}^{2+}$ (e.g., IN, PG, AR) are relative important. There are also important differences among the brines of these salars. For instance, DI, PC and AN show wide variations in the proportions of most cations, while RG, RI, IN, HM, and CE have relatively constant values across the salar. In general, with the exception of RA, salars located in the western side of the Southern Puna are richer in $\mathrm{Ca}^{2+}$ than those in the eastern side, which in turn, are relatively enriched in $\mathrm{Mg}^{2+}$. 
The concentration of $\mathrm{SO}_{4}{ }^{2-}$ in western salars is generally higher than that in the eastern side, representing intermediated values between the latter (lower $\left.\mathrm{SO}_{4}{ }^{2-}\right)$ and the salars from Northern Puna studied by López Steinmetz et al. (2018) (higher $\mathrm{SO}_{4}{ }^{2-}$ ). Another remarkable difference between Southern and Northern Puna is a clearly higher concentration of $\mathrm{Mg}^{2+}$ in the southern salars. These ionic patterns could be related to the characteristics of lithologic substrates. The basement rocks differ between the southern and northern portion of the Puna plateau: while Ordovician metasedimentary sequences predominate in the north, a metamorphic-magmatic basement (biotite gneiss, felsic granulites) prevails in the south (Lucassen et al., 2011; Bahlbourg et al., 2016; Egenhoff and Lucassen, 2003). Cenozoic andesitic and dacitic ignimbrites, associated with Miocene - Pliocene caldera complexes, largely cover the northern part of the Argentine Puna (particularly between $22^{\circ} 30^{\prime}-23^{\circ} \mathrm{S}$ ), whereas they are less abundant towards the south (de Silva, 1989; Caffe et al., 2002; Schnurr et al., 2007; Kay et al., 2010; Grosse et al., 2017, 2018; Montero López et al., 2015). Conversely, although mafic volcanism does occur in the North, the Southern Puna is characterized by a large number of Miocene-toQuaternary mafic monogenic volcanoes (285 centers; Barcelos Haag et al., 2019), which are typically formed of Mg-rich basaltic andesites (Maro et al., 2017a). They are characterized by more primitive compositions than those in the north (Maro et al., 2017b). Lavas with more alkaline compositions (i.e., basaltic trachyandesites with near shoshonite compositions) are rare across the Puna, and occur mostly towards the eastern side of this region (Maro \& Caffe, 2013). It is thus possible that the higher $\mathrm{Mg}^{2+}$ concentrations in the Southern Puna's salars are a consequence of weathering (and alteration?) of mafic rocks, whereas the sulfate increase in the Northern Puna probably derives from the Ordovician metasedimentary sequences. This is consistent with observations by López Steinmetz (2017) concerning the Guayatayoc salar area, who suggested that weathering of certain sections of the Ordovician basement (Santa Rosita Formation; Turner, 1960; Moya, 1988) made of marine mudstones, fine- grained silty 
sandstones, and shales (Buatois and Mángano, 2003) caused releasing of abundant $\mathrm{SO}_{4}{ }^{2-}$ (López

Steinmetz, 2017).

The data presented above indicates that the chemistry of most brines evolves through the sulfated pathway, with only a minor portion of samples passing through the calcic-sulfated way (Hardie and Eugster, 1970; Fig. 7). Among our samples, the brines from IN stand out by having the highest concentration in $\mathrm{Mg}^{2+}$ (Figs. 4A and 5C), while the remaining samples evolve through the calcic pathway, given that they are $\mathrm{Ca}^{2+}$ and $\mathrm{Mg}^{2+}$ rich with respect to $\mathrm{CO}_{3}{ }^{2-}$ and $\mathrm{SO}_{4}{ }^{2-}$. Based on the above observations, one can outline a relationship between the chemistry of brines that evolve through the calcic pathway and the local geology (Fig. 2 A): i) the high concentrations of $\mathrm{Mg}^{2+}$ that characterize brines from Incahuasi are probably related to the Cerro Oscuro Formation (consisting of continental red beds; Galli et al., 2010), which outcrops in the ranges just east of this salar (note that there are no monogenic volcanoes - i.e., Mg-rich basaltic andesites - just next to Incahuasi; Fig. 2); ii) the ionic proportions of $\mathrm{Ca}^{2+}+$ $\mathrm{Mg}^{2+}>\mathrm{CO}_{3}{ }^{2-}+\mathrm{SO}_{4}{ }^{2-}$ generally correspond to samples that were collected adjacent to outcrops that dominated by Quaternary sedimentary and volcanic rocks. In contrast, salars having brines that evolve through the sulfated pathway are adjacent to basement sequences consisting mostly of intrusive and volcanic units. This strongly suggests an igneous source for the sulfur, although some $\mathrm{SO}_{4}{ }^{2-}$ was probably released from weathering of metasediments.

In the five western salars, the decreasing order of average salinity is $A R \geq P C \geq R G \geq$ $\mathrm{RI} \geq \mathrm{AN}$ (Fig. 8). The concentrations of $\mathrm{Ca}^{2+}, \mathrm{Na}^{+}, \mathrm{K}^{+}, \mathrm{B}$, and $\mathrm{Li}^{+}$decrease according to [RG, $\mathrm{RI}, \mathrm{AR}] \geq[\mathrm{AN}, \mathrm{PC}]$. In the seven eastern salars, the decreasing order of average salinity is PZ $\geq \mathrm{PG} \geq \mathrm{HM} \geq \mathrm{IN} \geq \mathrm{DI} \geq \mathrm{RA} \geq \mathrm{CE}$. In addition to salinity, the magnitude of $\mathrm{Na}^{+}, \mathrm{Li}^{+}, \mathrm{Cl}^{-}$, and B concentrations can be summarized by $[\mathrm{PZ}, \mathrm{HM}, \mathrm{PG}] \geq[\mathrm{RA}, \mathrm{DI}, \mathrm{CE}, \mathrm{IN}]$. Although this pattern is valid, there are local variations and there is no recognizable concentration pattern for the remaining ions. According to the above, there would be no spatial (i.e., geographic) 
correlation with the ionic concentrations of these elements nor with $\mathrm{Li}^{+}$. Nonetheless, as mentioned previously, the concentrations of $\mathrm{SO}_{4}{ }^{2-}$, and in a lesser extent also those of $\mathrm{Mg}^{2+}$, do follow spatial patterns.

\subsection{Li concentration patterns}

Variations in the grades of $\mathrm{Li}$ in the brines of these salars can be assessed by plotting $\mathrm{Li}^{+}$concentration against salinity and other conservative solutes such as $\mathrm{Na}^{+}$in the brines. Figure 9 shows a general correlation for these parameters. This pattern is consistent with the incompatible geochemical behaviour of Li, i.e., it becomes enriched in the residual brine during salar evolution, a proxy of which is an increase in salinity. Another remarkable correlation can be observed between maximum $\mathrm{Li}^{+}$grades measured in brines and salar size (Fig. 10). This pattern is common to all of the salars studied in Argentina, including those from the Northern Puna (López Steinmetz et al., 2018). The best correlations can be observed among salars with surfaces smaller than about $400 \mathrm{~km}^{2}$. These show two positive trends: i) the Guayatayoc - RI Salinas Grandes - HM trend, represented by a regression line with a linear correlation (R; Pearson correlation coefficient) of 0.80 ; and ii) the IN, RA, JA, DI, CE, RG, PG, PZ, OL, and CA salars, which follow a linear trend characterized by $\mathrm{R}=0.84$. This feature suggests a relationship between $\mathrm{Li}^{+}$grade and salar size, in addition to, of course, other major determining factors that have been pointed out by Munk et al. (2016), such as the existence of Li supplying sources, hydrological isolation, aridity, etc. A clear trend between $\mathrm{Li}^{+}$grade and salar size exists for the smaller salars, while those of AR, AN and PC do not show as good a correlation, most likely because their surfaces are much larger (up to three orders of magnitude), over diluting the effect. Accordingly, larger salars would be expected to contain higher $\mathrm{Li}^{+}$grade brines than smaller ones, which provides a useful criterion for the surveying of brine-type deposits. 
The correspondence between the maximum $\mathrm{Li}^{+}$grades and salar sizes could be indicative of the importance of basin scale processes such as rock weathering, isolation and evaporation. In this sense, it is important to note that it has been recently shown that brines in Atacama formed in a near surface setting, through geochemical processes including lowtemperature weathering, evaporation, formation of transition zone brines (i.e., those with conductivity ranging between of 5 and $150 \mathrm{mS} / \mathrm{cm}$ ), and ultimately halite crystallization to drive Li concentration (in the brine) to the highest levels (Munk et al., 2018). Moreover, recent studies reported that Li content and isotopic composition in the Cenozoic volcanic rocks of the Central Andes can be explained by assimilation of the Paleozoic basement, and that volcanic and Paleozoic basement rocks are considered to be the primary source of Li in the Andean plateau (García et al., 2019; Meixner et al., 2019). These elements may help understanding the lack of spatial pattern in the regional $\mathrm{Li}$ distribution. The fact that $\mathrm{Li}$ is sourced from a lithologic sequence that is widespread across the entire Puna would rule out a geographic control. Rather, consistently increasing Li grades with salar size define a pattern that depends on basin scale processes, on geomorphology and, perhaps, also on the age of the basin (i.e., older basins would have more time than younger ones to stock the products of weathering and evaporation).

\subsection{The Li-bearing Southern Puna salars in an Andean context}

It is commonly assumed that brines enriched in Li also have high concentrations of $\mathrm{K}$ and $\mathrm{B}$. In Li brine-type deposits, $\mathrm{K}$ is typically obtained during Li recovering processes via brine evaporation, and borate mines are widespread in Andean salars. Positive trends between $\mathrm{Li}^{+}-\mathrm{K}^{+}$and $\mathrm{Li}^{+}-\mathrm{B}$ have been observed in CE, IN, PZ, AN, and PC (Fig. 6). Similar patterns have been also reported in salars of the Northern Puna. Furthermore, positive correlations might also exist between $\mathrm{Li}^{+}-\mathrm{Mg}^{2+}$ and $\mathrm{K}^{+}-\mathrm{Mg}^{2+}$ in $\mathrm{CE}, \mathrm{AN}, \mathrm{RI}, \mathrm{RG}$, and the Northern Puna's salars 
of Olaroz, Cauchari, Salinas Grandes, and Jama. These features could suggest common sources and a similar geochemical behavior for these ions.

Boron isotopic studies reported in the literature for the Puna region suggest the existence of two distinctive sources of $\mathrm{B}$, one associated with volcanic activity controlling borate precipitation in western Puna salars, and another one related to weathering of basement rocks, prevailing in the eastern Puna (Kasemann et al., 2004). Accordingly, given the better correlation between $\mathrm{Li}^{+}$and $\mathrm{B}$ in the eastern Puna salars, we suggest that some of their $\mathrm{Li}^{+}$and $\mathrm{B}$ may have been provided by weathering of the Ordovician basement. Furthermore, Peralta Arnold et al. (2017) reported isotopic data $\left(\delta^{18} \mathrm{O}\right.$ and $\left.\delta \mathrm{D}\right)$ coupled with high lithium concentrations in mature thermal waters (between 4 to $80 \mathrm{mg} \mathrm{L}^{-1}$ ) and in waters recycling evaporites (up to $600 \mathrm{mg} \mathrm{L}^{-1}$ ), which revealed that rock weathering is likely a significant suppling process for these salars.

A comparison between the concentrations of TDS-normalized ions (Figs. 8 and 11) allows assessing the relative abundance of $\mathrm{Li}^{+}$and other ions with respect to salinity (i.e., brine evolution and concentration through evaporation). Our data reveal that, relatively to those of their respective neighboring salars, brines from HM, DI, AR and IN are proportionally richer in $\mathrm{K}^{+}$(Fig. 11D), those from $\mathrm{AR}$ and $\mathrm{AN}$ are richer in $\mathrm{B}$ (Fig. $11 \mathrm{~F}$ ), and the CE, PG, and $\mathrm{HM}$ brines are the richest in $\mathrm{Li}^{+}$(Figs. $8 \mathrm{~B}$, and 11). IN and, to a lesser extent, $\mathrm{AR}$ and $\mathrm{DI}$, also contain the highest TDS-normalized $\mathrm{Mg}^{2+}$ grades in the Southern Puna (Fig. 11). The Salar de Arizaro, the largest salar of the Argentine Puna, has a mean $\mathrm{Li}^{+}: \mathrm{Mg}^{2+}$ of only 0.16 , similar to that of Atacama in Chile (Fig. 12, Table 2). It is important to note that reference values of the mean $\mathrm{Li}^{+}: \mathrm{Mg}^{2+}$ ratio in operating Li brine-type mines of the Andean plateau are highly variable: 0.16 in Atacama, 0.89 in Olaroz, and $\sim 0.90$ in Hombre Muerto (Ericksen and Salas, 1977; Risacher and Fritz, 1991; Godfrey et al., 2013; López Steinmetz et al., 2018; see Fig. 12 and $\mathrm{Li}^{+}: \mathrm{Mg}^{2+}$ ratios summarized in Table 2). Therefore, in operative terms, there is no strict threshold values to be considered as an acceptable $\mathrm{Li}^{+}: \mathrm{Mg}^{2+}$ ratio. Quite the reverse, Li grades 
define the major criteria to operate a brine-type project (Fig. 12). Additionally, and subsidiary to $\mathrm{Li}$ grades, the attractiveness of a Li brine-type mining project will also be reliant on the $\mathrm{Li}^{+}: \mathrm{Mg}^{2+}$ ratios and salar size and shape, as larger and more near-circular salt pans are better able to support long-term extraction than smaller ones or those having elongated shapes (Houston et al., 2011). Moreover, the resource estimate of a salt pan considers the aquifer geometry and the area of the concession, as deposits having a higher storage (i.e., the scale of the recoverable reserve of brine) provide, in general, more economic interest than smaller ones to develop Li brine-type mining (Gruber et al., 2010; López Steinmetz and Fong, 2019).

The Southern Puna remains a very remote and difficult to access region, due to poor roads conditions. Because of this, the location of salars in the Southern Puna is a constraint for operations compared with those located in the northern part, where roads and distances are suitable. Nevertheless, comparing Li grades, mean $\mathrm{Li}^{+}: \mathrm{Mg}^{2+}$ ratios, and salar sizes can provide a rapid evaluation of the relative mining potential of these salars with respect to Li extraction (Fig. 12). Applying these considerations to the salars that are not being operated, the most interesting targets in Southern Puna are the Salar de Arizaro (the largest salt pan of the Argentine Puna), Antofalla-Botijuelas (which has interesting Li:Mg ratios and a large surface, though its elongated shape could be a constraint), and Pastos Grandes, Pozuelos, and Rincón (which have encouraging Li grades, interesting sizes, and relatively easy access). These salars embody interesting perspectives in a regional context.

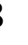

\section{Conclusions}

This study reports the results of a regional geochemical survey of Li brines, covering the Southern Puna of Argentina. Brines from the twelve major salars in this region are characterized by mean $\mathrm{Li}^{+}$concentrations varying by up to one order of magnitude, from 57 to $570 \mathrm{mg} \mathrm{L}^{-1}$, with mean Li:Mg ratios ranging from 0.01 to 1.24 . 

presented in this contribution reveal likely correlations between the concentrations of $\mathrm{Li}^{+}, \mathrm{K}^{+}$, $\mathrm{B}$, and $\mathrm{Mg}^{2+}$, suggesting common sources and similar geochemical behavior for these ions. No geographical pattern for the $\mathrm{Li}^{+}$concentrations has been observed. However, salar size could be related to maximum $\mathrm{Li}^{+}$grade of brines. Larger salars would then be expected to contain higher $\mathrm{Li}^{+}$grade brines than smaller ones, making salar size a useful criterion for surveying brine-type deposits.

The comparison between mean $\mathrm{Li}^{+}$grades, $\mathrm{Li}^{+}: \mathrm{Mg}^{2+}$ ratios, and salar size provides an assessment of the Li potential offered by a number of salars in the Souther Puna: Arizaro because of it dimension, Pastos Grandes, Pozuelos, and Rincón due to Li grades and accessibility, and Antofalla-Botijuelas on account of its Li:Mg ratios. In addition to these salars, Río Grande and Salinas Grandes have a remarkable brine chemistry. Olaroz, Cauchari, and Hombre Muerto contain the highest $\mathrm{Li}^{+}$grades in brines of all of the Argentine Puna, and represent the most interesting perspectives of the Argentine plateau and in a regional context.

\section{Acknowledgments}

550 The authors wish to thank EG editor L. Meinert for his help throughout the reviewing process and two anonymous reviewers for their constructive comments which led to significant improvements of this manuscript. This study was founded by grant 2016-2017 and 2018-2019 of the SECTER - UNJu. Special thanks to Capt. Christian Meuric for large field logistical support. There are no conflicts of interest to declare.

\section{References} Argentino, Actas v. 4, p. 3-18. 
Aceñolaza, F.; Benedetto, L.; Salfity, J., 1972, El Neopaleozoico de la Puna: su fauna y correlación con áreas vecinas: Anales de la Academia Brasilera de Ciencias, v. 44, p. 520.

Alonso, R.N., 1986, Ocurrencia, Posición Estratigráfica y Génesis de los Depósitos de Boratos de la Puna Argentina: Unpublished PhD Thesis, Universidad Nacional de Salta, 196 pp.

Alonso, R.N.; Gutiérrez, R.; Viramonte, J., 1984, Puna Austral - Bases para el subprovincialismo geológico de la Puna Argentina: 9th Congreso Geológico Argentino, Actas v. 1, p. 43-63.

Alonso, R.N.; Viramonte, J.G., 1987, Geología y metalogenia de la Puna: Estudios Geológicos, v. 43 , p. 393-407.

Alonso, R.N.; Jordan, T.E.; Tabbutt, K.T.; Vandervoordt, D.S., 1991, Giant evaporite belts of the Neogene central Andes: Geology, v. 19 (4), p. 401-404.

Bahlburg, H.; Berndt, J.; Gerdes, A.; 2016, The ages and tectonic setting of the Faja Eruptiva de la Puna oriental, Ordovician, NW Argentina: Lithos, v. 256-257, p. 41-54.

Barcelos Haag, M.; Beaz, W.; Sommer, C.A.; Arnosio, J.M.; Filipovich, R.E., 2019, Geomorphology and spatial distribution of monogenic volcanoes in the southern Puna plateau (NW Argentina): Geomorphology, v. 342, p. 196-209.

Buatois, L.A.; Mángaro, M.G., 2003, Sedimentary facies, depositional evolution of the Upper Cambrian-Lower Ordovician Santa Rosita formation in northwest Argentina: Journal of South American Earth Sciences, v. 16, p. 343-363.

Caffe, P.J.; Trumbull, R.B.; Coira, B.L.; Romer, R.L., 2002, Petrogénesis of Early Neogene magmatism in the Northern Puna; implications for magma genesis and crustal processes in the Central Andean Plateau: Journal of Petrology, v. 43, p. 907-942.

Clesceri, L.S.; Greenberg, A.E.; Eaton, A.D., 1998, Standard Methods for the Examination of Water and Waste Water: Amer. Public. Health. Assoc., 20 $0^{\text {th }}$ Edition, USA. 
Coira, B., 1979, Descripción geológica de la Hoja 3c: Servicio Geológico Nacional. Buenos Aires, Boletín 170.

de Silva, S.L., 1989, Altiplano-Puna volcanic complex of the central Andes: Geology, v. 17, p. 1102-1106.

Donato, E.; Vergani, G., 1985, Geología del Devónico y Neopaleozoico de la zona del Cerro Rincón, Salta, Argentina: 4th Congreso Geológico Chileno, Actas v. 1 (1), p. 262-283.

Egenhoff, S.O.; Lucassen, F., 2003, Chemical and isotopic composition of lower to upper Ordovician sedimentary rocks (Central Andes /South Bolivia): implications for their source: Journal of Geology, v. 111, p. 487-497.

Ericksen, G.E.; Salas, R., 1977, Geology and resources of salars in the central Andes: U.S. Geologial Survey, Open File Repository 88-210, 51 pp.

Galli, C.I.; Moya, M.C.; Arnosio, M., 2010, Estudios sedimentológicos en los depósitos carboníferos y pérmicos del borde occidental de la Puna: Revista de la Asociación Geológica Argentina, v. 66, p. 119-132.

García, M.G.; Borda, L.G.; Godfrey, L.V.; López Steinmetz, R.L.; Losada Calderón, A., 2019, Characterization of lithium cycling in the Salar de Olaroz, Central Andes, using a geochemical and isotopic approach: Chemical Geology, v. 531, 119340, https://doi.org/10.1016/j.chemgeo.2019.119340.

Garrett, D.E., 2004, Handbook of lithium and natural calcium chloride: their deposits, processing, uses and properties: Elsevier Academic Press, 1st edition.

Ghadbeigi, L.; Harada, J.K.; Lettiere, B.R.; Sparks, T.D., 2015, Performance and resource considerations of Li-ion battery electrode materials: Energ. Environ. Sci., v. 8, p. 16401650. 
Godfrey, L.V.; Chan, L.-H.; Alonso, R.N.; Lowenstein, T.K.; McDonough, W.F.; Houston, J.; Li, J.; Bobst, A.; Jordan, T.E., 2013, The role of climate in the accumulation of lithiumrich brine in the Central Andes: Applied Geochemistry, v. 38, p. 92-102.

Grosse, P.; Guzmán S.; Petrinovic, I.A., 2017, Volcanes compuestos cenozoicos del noroeste argentine: 20 Congreso Geológico Argentino, Relatorio, 484-517.

Grosse, P.; Orihashi, Y.; Guzmán, S.; Sumino, H.; Nagao, K., 2018, Eruptive history of Incahuasi, Falso Azufre and El Cóndor Quaternary composite volcanoes, southern Central Andes: Bulletin of Volcanology, v. 80, 44.

Gruber, P.W.; Medina, P.A.; Keoleian, G.A.; Kesler, S.E.; Everson, M.P.; Wallington, T.J., 2010, Global lithium availability: a constraint for electric vehicles? : Journal of Industrial Ecology, v. 15, p. 760-775.

Hache, E.; Bonnet, C.; Seck, G.S.; Simoën, M., 2018, Les matériaux de la transition énergétique : le lithium: The Conversation 24 October 2018 https://theconversation.com/les-materiaux-de-la-transition-energetique-le-lithium105429.

Hardie, L.; Eugster, H., 1970, The evolution of closed-basin brines. Fiftieth Anniversary Symposia, Mineralogy and Geochemistry of Non-Marine Evaporites: Mineralogical Society of America Special Publication, p. 273-290.

Houston, J.; Butcher, A.; Ehren, P.; Evans, K.; Godfrey, L., 2011, The evaluation of brine prospects and the requirement for modifications to filing standards: Economic Geology, v. 106, p. $1225-1239$.

Ide, F.; Kunasz, I.A., 1989, Origin of lithium in Salar de Atacama, northern Chile, in: Ericksen, G.E., Cañas, M.T., Pinochet, J.A., Reinemund, R., eds., Geology of the Andes and its relation to hydrocarbon and mineral resources, Circum-Pacific Council for Energy and Mineral Resources, Earth Science Series, v. 11, p. 165-172. 
Jordan, T.; Alonso, R.N., 1987, Cenozoic stratigraphy and basin tectonics of the Andes Mountain: American Association of Petroleum Geologist, v. 71, p. 49-64.

Kaseman, S.A.; Meixner, A.; Erzinger, J.; Viramonte, J.G.; Alonso, R.N.; Franz, G., 2004, Boron isotope composition of the geothermal fluids and borate minerals from salar deposits (central Andes / NW Argentina): Journal of South American Earth Sciences, v. 16, p. 685-697.

Kesler, S.E.; Gruber, P.W.; Medina, P.A.; Keoleian, G.A.; Everson, M.P.; Wallington, T.J., 2012, Global lithium resources: relative importance of pegmatites, brine and other deposits: Ore Geology Revues, v. 48, p. 55-69.

Kay, S.M.; Coira, B.L.; Caffe, P.J.; Chen, C.H., 2010, Regional chemical diversity, crustal and mantle sources and evolution of central Andean Puna plateau ignimbrites: Journal of Volcanology and Geothermal Research, v. 198, p. 81-111.

Kunasz, I.A., 2006, Lithium resources. In Industrial minerals and rocks, commodities, markets and uses. 7th edition.

López Steinmetz, R.L., 2017, Lithium- and boron-bearing brines in the Central Andes: exploring hydrofacies on the eastern Puna plateau between $23^{\circ}$ and $23^{\circ} 30^{\prime} \mathrm{S}$ : Mineralium Deposita, v. 52, p. 35-50.

López Steinmetz, R.L.; Galli, C.I., 2015, Hydrological change during the Pleistocene-Holocene transition associated with the Last Glacial Maximum-Altithermal in the eastern border of northern Puna: Andean Geology, v. 42 (1), p. 1-19.

López Steinmetz, R.L.; Salvi, S.; García, M.G.; Béziat, D.; Franco, G.; Constantini, O.; Córdoba, F.; Caffe, P.J., 2018, Northern Puna plateau-scale survey of Li brine-type deposits in the Andes of NW Argentina: Journal of Geochemical Exploration, v. 190, p. 26-38. 
López Steinmetz, R.L.; Fong, S.B., 2019. Water legislation in the context of lithium mining in Argentina: Resources Policy, v. 64, 101510.

Lucassen, F.; Becchio, R.; Franz, G., 2011, The early Palaeozoic high grade metamorphism at the active continental margin of West Gondwana in the Andes (NWArgentina/N Chile): International Journal of Earth Sciences (Geologische Rundschau), v. 100, p. 445-463.

Maro, G.; Caffe, P.J., 2013, Primer registro de lavas shoshonı'ticas en Puna norte, el cerro Barro Negro: 2 Simposio sobre Petrología Ignea y Metalogénesis Asociada, San Luis, Actas, $51 \mathrm{pp}$.

Maro, G.; Caffe, P.J.; Báez, W., 2017a, Volcanismo monogenético máfico cenozoico de la Puna: 20 Congreso Geológico Argentino, Relatorio, p. 584-577.

Maro, G.; Caffe, P.J.; Romer, R.L.; Trumbull, R.B., 2017b, Neogene mafic magmatism in the Northern Puna plateau, Argentina: generation and evolution of a back-arc volcanic suite: Journal of Petrology, v. 58, p. 1591-1618.

Meixner, A.; Sarchi, C.; Lucassen, F.; Becchio, R.; Caffe, P.J.; Lindsay, J.; Rosner, M.; Kasemann, S.A., 2019, Lithium concentrations and isotope signatures of Palaeozoic basement rocks and Cenozoic volcanic rocks from the Central Andean arc and back-arc: Mineralium Deposita, doi: 10.1007/s00126-019-00915-2.

Méndez, V.; Navarini, A.; Plaza, D.; Viera, O., 1973, Faja Eruptiva de la Puna oriental: 5th Congreso Geológico Argentino, Actas v. 4, p. 89-100.

Méndez, V.; Turner, J.C.; Navarin, A.; Amengual, R.; Viera, O., 1979, Geología de la región Noroeste. Argentina: Dirección General de Fabricaciones Militares. Buenos Aires, 118 pp.

Moya, M.C., 1988, Lower Ordovician in the Southern part of the Argentine Eastern Cordillera, in: Bahlburg, H., Breitkreuz, Ch., P. Giese, eds., The Southern Central Andes, Springer, Berlin, p. 55-69. 
681

682

683

684

685

686

687

688

689

690

691

692

693

694

695

696

697

698

699

700

701

702

703

704

705

Montero López, C.; Guzmán, S.; Barrios, F., 2015, Late Miocene ignimbrites at the southern Puna- northern Sierras Pampeanas border $\left(\sim 27^{\circ} \mathrm{S}\right)$ : stratigraphic correlation: Journal of South America Earth Sciences, v. 62, p. 89-91.

Munk, L.A.; Hynek, S.A.; Bradley, D.; Boutt, D.; Labay, K.; Jochens, H., 2016, Lithium brines: A Global Perspective: Reviews in Economic Geology, v. 18, p. 339-365.

Munk, L.A.; Boutt, D.F.; Hynek, S.A.; Moran, B.J., 2018, Hydrogeochemical fluxes and processes contributing to the formation of lithium-enriched brines in a hyper-arid continental basin: Chemical Geology, v. 493, p. 37-57.

Olivetti, E.A.; Ceder, G.; Gaustad, G.G.; Fu, X., 2017, Lithium-Ion Battery Supply Chain Considerations: Analysis of Potential Bottlenecks in Critical Metals: Joule, v. 1, p. 229243.

Orberger, B.; Rojas, W.; Millot, R.; Flehoc, C., 2015, Stable isotopes (Li, O, H) combined with chemistry: powerful tracers for Li origins in Salar deposits from the Puna region, Argentina: Procedia Earth and Planetary Science, v. 13, p. 307-311.

Ovejero Toledo, A.; Alonso, R.N.; Ruiz, T.; Quiroga, A.G., 2009, Evapofacies halítica en el Salar del Rincón, Departamento Los Andes, Salta: Revista de la Asociación Geológica Argentina, v. 64 (3), p. 493-500.

Peralta Arnold, Y.J.; Cabassi, J.; Tassi, F.; Caffe, J.P.; Vaselli, O., 2017. Fluid geochemistry of a deep-seated geothermal resource in the Puna plateau (Jujuy Province, Argentina): Journal of Volcanology and Geothermal Research, doi: 10.1016/j.jvolgeores.2017.03.030.

Risacher, F.; Fritz, B., 1991, Quaternary geochemical evolution of the Salar of Uyuni and Coipasa, Central Altiplano, Bolivia: Chemical Geology, v. 90, p. 211-231.

Risacher, F.; Fritz, B., 2009, Origin of salt and brine evolution of Bolivian and Chilean Salars: Aquat. Geochemistry, v. 15, p. 123-157. 
Salfity, J.; Gorustovich, S.; Moya, C.; Amengual, R., 1984, Marco tectónico de la sedimentación y la efusividad cenozoicas en la Puna argentina: 9th Congreso Geológico Argentino, Actas v. 1, p. 539-554.

Schnurr, W.B.W.; Trumbull, R.B.; Clavero, J.; Hahne, K.; Siebel, W; Gardeweg, M., 2007, Twenty-five million years of silicic volcanism in the southern central volcanic zone of the Andes: geochemistry and magma genesis of ignimbrites from 25 to $27 \mathrm{~S}, 67$ to $72 \mathrm{~W}$ : Journal of Volcanology and Geothermal Research, v. 166, p. 17-46.

Schwab, K., 1973, Die Stratigraphie in der umbebung des salar Cauchari : Geotekt. Forsch., v.43, $168 \mathrm{pp}$.

Sun, X.; Hau, H.; Zhao, F.; Liu, Z., 2017, Tracing global lithium flow: A trade-linked material flow analysis: Resources, Conservation \& Recycling, v. 124, p. 50-61.

Turner, J.C., 1960, Estratigrafía del Nevado de Cachi y sector oeste: Acta Geológica Lilloana, v. 3, p. 191-226.

Turner, J.C. ; Méndez, V., 1979, Puna : Geología Regional Argentina, v. 1, p. 13-56. Buenos Aires.

Vinante, D.; Alonso, R.N., 2006, Evapofacies del salar de Hombre Muerto, Puna argentina: distribución y génesis: Revista de la Asociación Geológica Argentina, v. 61 (2), p. 286297.

\section{Figure Captions}

Fig.1. (A) Schematic map showing the location and geographic environment of the Puna plateau in the Central Andes. The thick dashes separate the areas known as Altiplano, Northern and Southern Puna (modified from López Steinmetz et al., 2018). (B) Location map zooming on 
Argentinian Puna, showing the main salars in this region. Figure B is a subset of Figure A. 1: Guayatayoc; 2: Salinas Grandes; 3: Olaroz; 4: Cauchari; 5: Jama; 6: Pastos Grandes; 7 : Pozuelos; 8: Centenario; 9: Ratones; 10: Diablillos; 11: Hombre Muerto; 12: Incahuasi; 13: Antofalla-Botijuelas; 14: Río Grande; 15: Arizaro; 16: Pocitos-Quirón; 17: Rincón.

Fig. 2. (A) Schematic geological map of Southern Puna showing the location of eleven considered salars (modified from Alonso and Viramonte, 1987). Insets display in detail the location of shallow brine sampling sites (colored crosses) and corresponding Li grades (mg L$\left.{ }^{1}\right)$ of each salar located along the eastern border of the Southern Puna: Pastos Grandes (PG), Pozuelos (PZ), Centenario (CE), Ratones (RA), Diablillos (DI), Hombre Muerto (HM), and Incahuasi (IN). ). The western Southern Puna salars are: Antofalla-Botijuelas (AN), Río Grande (RG), Pocitos-Quirón (PC), Rincón (RI), and Arizaro (AR). Precise latitude and longitude of the samples are given in Table A1 of the Appendix. Lithological legend: 1) modern salar; 2) lagoon; 3) muddy salt flat; 4) Quaternary alluvial deposits, including piedmonts, alluvial fans and alluvial plains; 5) Quaternary basalt; 6) Neogene dacite, andesite, and ignimbrite; 7) Cenozoic sedimentary units (Pastos Grandes Group); 8) upper Paleozoic sedimentary units (Cerro Oscuro and Arizaro Formations); 9) Eastern Puna Eruptive Belt; 10) Ordovician metasedimentary rocks (Copalayo, Caucota, and Falda Ciénaga Formations), including ultramafic intrusions and inter-stratified volcanic rocks.

Fig. 3. Schematic maps displaing the location of shallow brine sampling sites (colored crosses) and corresponding Li grades $\left(\mathrm{mg} \mathrm{L}^{-1}\right)$ in salars located across the western Southern Puna: Antofalla-Botijuelas (AN), Río Grande (RG), Pocitos-Quirón (PC), Rincón (RI), and Arizaro (AR). The location of insets is provided in Figure 2A. Precise latitude and longitude of the 
767

768

777

778

samples are given in Table A1 of the Appendix. Lithological legend as for Figure 2, plus 11) thermal spring.

Fig. 4. Ternary diagrams displaying relative ionic concentrations $\left(\mathrm{mg} \mathrm{L}^{-1}\right)$ measured in brines from salars of the Southern Puna. A) Salars of the eastern area. B) Salars of the western part. Salar abbreviations are Antofalla-Botijuelas (AN), Arizaro (AR), Centenario (CE), Ratones (RA), Diablillos (DI), Hombre Muerto (HM), Incahuasi (IN), Pastos Grandes (PG), PocitosQuirón (PC), Pozuelos (PZ), Rincón (RI), and Río Grande (RG).

Fig. 5. Scatter diagrams plotting the concentrations of $\mathrm{Na}^{+}$versus $\mathrm{Cl}^{-}(\mathrm{A}), \mathrm{Ca}^{2+}$ versus $\mathrm{CO}_{3}^{2-}$ $+\mathrm{HCO}_{3}{ }^{-}(\mathrm{B}), \mathrm{Ca}^{2+}$ versus $\mathrm{SO}_{4}{ }^{2-}(\mathrm{C})$, and $\mathrm{Mg}^{2+}$ versus $\mathrm{SO}_{4}{ }^{2-}(\mathrm{D})$, in the twelve salars from the Southern Puna. Abbreviations as in Fig. 4.

Fig. 6. Scatter diagrams showing the variation of the Li:K (A and B), the Li:B (C and D), and the Li:Mg (E and F) ratios in salars from the Southern Puna. A, C, E) Salars of the westen side. B, D, F) Salars of the eastern part. Abbreviations as in Fig. 4.

Fig. 7. Schematic diagram of Hardie and Eugster (1970, modified after Risacher and Fritz, 2009) illustrating flow paths of the evaporative composition of inflow waters with respect to salinity and composition, measured in the salars from Southern Puna. The ordinate axis plots the total dissolved load of the solution in $\mathrm{g} \mathrm{L}^{-1}$. Abbreviations as in Fig. 4.

Fig. 8. Diagram showing the salinity grades (A) and the TDS normalized concentrations of $\mathrm{Li}^{+}$ (B) of brines from Southern Puna salars. Abbreviations as in Fig. 4. 

in salars from the Southern Puna. Concentrations are expressed in $\mathrm{mg} \mathrm{L}^{-1}$. $\mathrm{R}$ is the Pearson correlation coefficient. Abbreviations as in Fig. 4.

Fig. 10. Scatter diagrams showing the correlations between the maximum measured $\mathrm{Li}^{+}$grade in brines and salar size, for the Puna plateau. $\mathrm{R}$ is the Pearson correlation coefficient. $\mathrm{Li}^{+}$-grade brine data and salar size for JA, OL, CA, SG, and GG are from López Steinmetz et al. (2018) and López Steinmetz (2017). Figure B is a subset of Figure A. Abbreviations as in Fig. 4, plus Guayatayoc (GG), Salinas Grandes (SG), Olaroz (OL), Cauchari (CA), Jama (JA) from Northern Puna (López Steinmetz et al., 2018).

Figure 11. Scatter diagrams showing the TDS-normalized concentrations of $\mathrm{Li}^{+}$versus $\mathrm{Cl}^{-}(\mathrm{A})$, $\mathrm{Li}^{+}$versus $\mathrm{Na}^{+}(\mathrm{B}), \mathrm{Li}^{+}$versus $\mathrm{CO}_{3}{ }^{2-}+\mathrm{HCO}_{3}{ }^{-}(\mathrm{C}), \mathrm{Li}^{+}$versus $\mathrm{K}^{+}(\mathrm{D}), \mathrm{Li}^{+}$versus $\mathrm{Mg}^{2+}(\mathrm{E})$, and $\mathrm{Li}^{+}$versus B (F) in salars of the Southern Puna. Abbreviations as in Fig. 4.

Figure 12. Scatter diagrams showing the variations of $\mathrm{Li}^{+}: \mathrm{Mg}^{2+}$ ratios versus salar size (A), and the variations of mean $\mathrm{Li}^{+}$concentrations versus $\mathrm{Li}^{+}: \mathrm{Mg}^{2+}$ ratios (B). The middle panel is a subset of Figure A. Abbreviations as in Fig. 10 plus Atacama (ATA) and Uyuni (UYU) from Chile and Bolivia, respectively (data from Ericksen and Salas, 1977; Risacher and Fritz, 1991). See Table 2 for data values. Note that regardless surfaces and $\mathrm{Li}: \mathrm{Mg}$ ratios (A), only salars having the highest Li grades are currently operated (B).

\section{Table Captions}


Table 1. Chemical composition of brines collected in salars of the Southern Puna: AntofallaBotijuelas (AN), Arizaro (AR), Centenario (CE), Diablillos (DI), Hombre Muerto (HM), Incahuasi (IN), Pastos Grandes (PG), Pocitos-Quirón (PC), Pozuelos (PZ), Rincón (RI), and Río Grande (RG).

Table 2. Comparative attributes of the Uyuni, Atacama, and the Argentine Puna's salars. The mean $\mathrm{Li}^{+}$a concentration and the $\mathrm{Li}: \mathrm{Mg}^{\text {a }}$ ratio in Uyuni corresponds to the mean values of 38 samples (from sample 100 to sample 133 and samples 146, 147 and 147A) reported by Ericksen and Salas (1977). The mean $\mathrm{Li}^{+} \mathrm{b}$ concentration and $\mathrm{Li}: \mathrm{Mg}{ }^{\mathrm{b}}$ ratio corresponds to mean values of the 164 samples (from sample UA to sample RZ) reported by Risacher and Fritz (1991). The mean $\mathrm{Li}^{+\mathrm{c}}$ concentration and $\mathrm{Li}: \mathrm{Mg}^{\mathrm{c}}$ ratio of Hombre Muerto correspond to the mean value of the 9 samples (samples 4, 5, 6, and 9 to 14) reported by Godfrey et al. (2013). The mean $\mathrm{Li}^{\mathrm{d}}$ concentration in Hombre Muerto corresponds to the mean $\mathrm{Li}^{+}$concentration of $100 \mathrm{~m}$-deep brines reported by Garret (2004) and Kesler et al. (2012). The mean $\mathrm{Li}^{+}$e concentration corresponds to the value reported by Ovejero Toledo et al. (2009) for brines at 10- to 50-m depth in the Salar del Rincón. Data for Guayatayoc correspond to values reported by López Steinmetz (2017), data for Jama, Olaroz, Cauchari, and Salinas Grandes are from López Steinmetz et al. (2018). Remaining data is original from this contribution (Table 1). 